التحري عن القتوات المائية تحت السطحية في الجزء الغزبي من سد الموصل بواسطة الانكسار الزلزالي

$$
\text { قبم علوم الأرضل بليز الجريسي }
$$

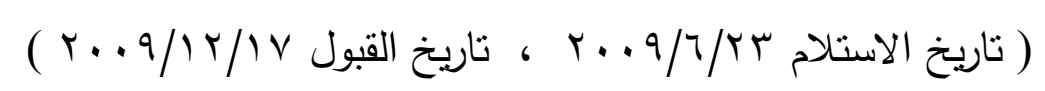

\title{
الملخص
}

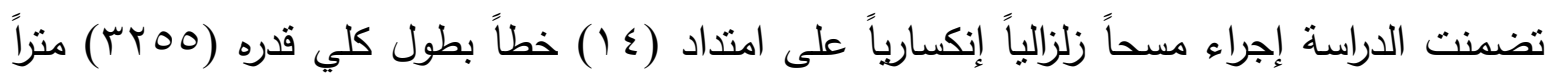

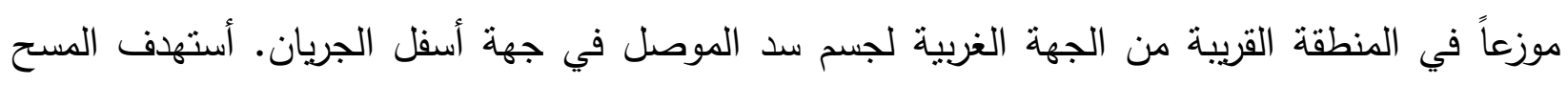

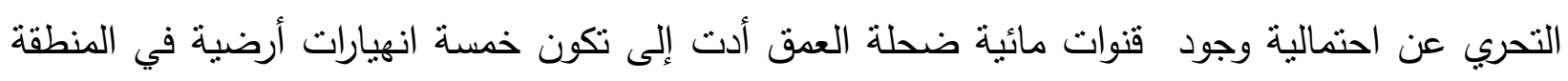
ومعرفة مصدر مياه هذه القنوات. أوضحت نتائج المسح بأن هنالك احتمالية لوجود قناة مائية ضحلة العمق يتراوح عمق سطحها العلوي

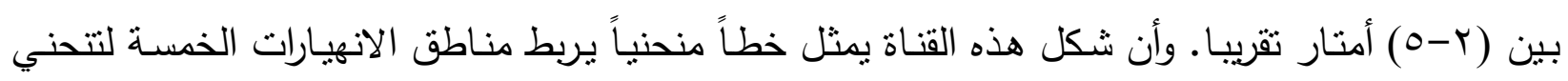

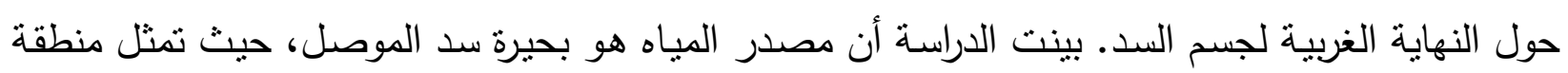
مرسى القوارب المأخذ لمياه هذه القناة لتصب في النهر في جهة أسفل الجريان محدثة انهيارات أرضية في لئي

\section{The Investigation of Subsurface Channels in the Western Part of Mosul Dam by Seismic Refraction}

\author{
Nabil H. Al-Saigh \\ Dams and Water Resources \\ Research Centre \\ Mosul University
}

\author{
Bashar A. Al-Juraisy \\ Department of Geology \\ College of Science \\ Mosul University
}

\section{ABSTRACT}

Fourteen seismic refraction traverses with a total length of (3255) $\mathrm{m}$ were distributed in the nearby area of the western part of Mosul dam in its downstream side. The aim of the survey is to investigate the possibility of presence of shallow 


$$
\text { نبيل حميد الصائغ و بشار عزيز الجريسي }
$$

subsurface channels that led to the formation of five sinkholes in the area and to establish the source of the channels' water.

The survey indicates the possibility of the presence of a shallow subsurface channel. The depth of the upper part of this channel ranges between ( 2 and 5) $\mathrm{m}$ below the ground surface. The shape of this channel represents a curved line bends across the western end of the dam body and joined the five sinkholes. The study showed that the source of the water is Mosul Dam Lake, where the landing boat area represents the main water intake and discharge to the Tigris River in the downstream side of the dam causing many sinkholes in the area. 